\title{
Management Issues in Loan Syndications Banking
}

\author{
Alexey Tarasov
}

Candidate of Economics,

Executive MBA,

Moscow, Russia

alexey.tarasov@outlook.com

http://orcid.org/0000-0002-7902-5619

Abstract

This article covers the key management issues in the loan syndications banking business. A syndicated loan is provided to a borrower by a group of commercial or investment banks. The global syndicated loan market is from one perspective, the primary funding source for corporations and on the other - one of the leading businesses for the global banks. There exist some unique challenges that must be responded by banks from a managerial and strategic perspective to establish and maintain leadership in the important business due to the features, structures, and industrial organisation of the market. We first consider how the loan syndications business is structured in a global bank, its functions and competitive advantages. Then we discuss the ways banks can implement an effective strategy and maintain leadership and growth in the market. Finally, we propose solutions to dealing with commoditization in banking: (i) adding more value-added services to the client offering; (ii) bundling of services in order to realize cross-selling opportunities and maximize share-of-wallet; (iii) further segmentation and customization of the client base (by industry/relationship/services consumption). By adopting these strategies, banks can successfully fight the commoditization magnet and increase the profitability of their loans syndications businesses.

Keywords: banking industry; syndicated loans; bank management; commoditization; international capital markets JEL classification: G24

\section{The Loans Syndications Business}

The syndicated loans market is one of the most important funding sources for corporations and financial institutions. Based on the information provided by (Bloomberg, 2018), the volume of the global syndicated loans market totalled USD 4.9 trillion in 2018, demonstrating a 9.4 per cent increase compared to 2017. During the year, the total number of deals decreased by 3.6 per cent to 8,359. JP Morgan ranked as the top global syndicated loans book-runner with 10.2 per cent market share. The bank acted as bookrunner in 1,336 deals in 2018. Bank of America Merrill Lynch and Citi ranked second and third with 9.2 per cent and 5.7 per cent of market share respectively.

A syndicated loan is provided to a borrower by a group of commercial or investment banks. Its main features are: (i) one set of documentation (multi-party facility agreement); (ii) the financing terms are identical for all lenders; (iii) equal ranking of all lenders; (iv) information flow and payments are channelled via one bank, the Facility Agent (Shutter, 2017). The deal is arranged by a leading international loan market banks, called the Coordinator. The Coordinator structures the transaction to suit the financing needs of the borrower and arranges a senior syndicate of banks that are called the Mandated Lead Arrangers. Then these banks, in the roles of Book-runners, run the syndication process in the global loan market, inviting investors to join the loan as Lenders (Tarasov, 2017). Based on the deal information package, that includes documents describing the business and financials of the borrower, the Lenders make the decision as regards their commitments in 
the deals. Following the signing of the Facility Agreement that is drafted by an international legal firm, the transactions are closed, and the funds are provided to the borrower.

In this article, we present an overview of management issues in loan syndications. The mission of the business is to provide syndicated financing solutions to the clients of the bank (Altunbas, Gadanecz \& Kara, 2006). The products are corporate loans, financial institutions loans, real estate finance, pre-export finance, project finance, advisory services (Caselli \& Gatti, 2017). Syndicated loans are one of the key offerings of all major international banks that are active in the corporate banking and capital markets businesses. Inside the bank, the loans syndications business is organised as a department inside the global financing business (Davis, 2002).

The functions of the Loan Syndications department include loan structuring and negotiations with the borrowers, preparation of the information package, participation in the drafting of acceptable loan documentation, running the syndication process among the investor base. An additional essential function is the management of the syndicated loans portfolio (Francis \& Kim, 2013). Since several parties are involved in a loan transaction (borrowers, investors, legal firms), a point fundamental to the success of the execution process is efficient management of the execution process in the role of the Coordinator. Another important aspect is the sectors that are covered by the department. These usually include natural resources, industrials, telecom, technology, distribution, transport, retail, financial institutions. As follows, such a structure envisages a vertically integrated loans business, providing a broad range of financing solutions to the client base (Iannotta, 2010).

The business is highly competitive, with all major international banking groups targeting the leading corporations and financial institutions that have investment-grade credit ratings and are therefore acceptable from a credit risk perspective (Dennis \& Mullineaux, 2000). These companies require high-quality service, low cost of borrowing, and massive funding capacities from banks, as well as advanced cross-selling products (interest rate and foreign currency derivatives (Wystup, 2017)) and services (advising on optimal capital structure, M\&A transactions (Allen, Peristiani \& Saunders,
2004)). Therefore, the competitive position of a bank in the loan market is determined by (Schwert, 2018): (i) cost of funding; (ii) capital capacity; (iii) ability to provide an integrated service offering.

The loan syndications business, if organised the right way, can lead to significant asset creation (growth of the balance sheet) and shareholder value creation (measured as the Return on Equity) for the bank. It can, therefore, be placed in the upper-right quadrant of the "mission critical/growth" framework in Figure 1, being a mission critical business (most corporate clients and financial institutions require syndicated loans) with high growth potential (in terms of selling additional products and services to existing borrowers).

\section{Application of the Concept of Strategic Leadership and Ambidexterity}

The syndicated loans market is a highly competitive one. All global banks view it as imperative to their corporate business offering and are ready to allocate significant resources (capital, headcount, technology) to gain market share (usually measured as the total amount of loans executed). For context, additional KPIs for loan syndications include the total number of deals, net banking income, cost-to-income ratio.

Based on the Bloomberg data, we can evaluate the strategic strength of the loan syndications business of a global bank using the following managerial framework:

- Attain and maintain leadership in the global syndicated loans market (measured as being in the top-10 banks with a market share exceeding 3.0 per cent).

- Annually execute more than 500 transactions, with a total volume of more than USD 125 billion.

- Diversification of the business in terms of industries (natural resources, industrials, telecom, technology, distribution, transport, retail, financial institutions) and loan products (corporate and financial institutions loans, real estate, pre-export and project finance transactions).

- Achieve the KPI targets set internally by the management of the bank.

For this strategy to be successful, there should be an alignment with the external environment to ensure customer value creation. The external environment is represented by other banks, funding requirements of borrowers, and the economic 


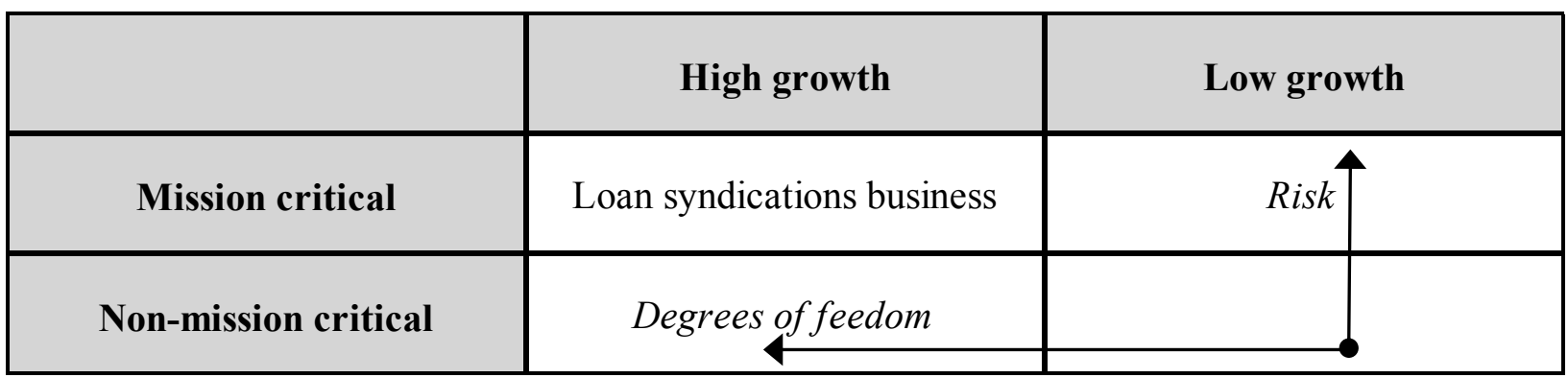

Fig. 1. Strategic positioning of the loan syndications business in a global bank.

Source: The author.

conditions in the financial markets. Customer value is the ability of the bank to efficiently meet the funding requirements of the borrowers in terms of loan structure (amount, price, tenor), execution services, and additional products.

To achieve market leadership, banks face several challenges, including (i) effective strategy implementation; (ii) maintenance of leadership and growth in the market; (iii) dealing with commoditization. These challenges are covered in the following sections.

As per (O’Reilly \& Tushman, 2011): “central to the ability of a firm to survive over time is its ability to exploit existing assets and positions in a profit-producing way and simultaneously to explore new technologies and markets - to configure and reconfigure organisational resources to capture existing as well as new opportunities". It is also a tool to manage the tension between the mission, the external context (strategic steps made by competing banks) and the internal context (the restructuring of the interior business of the bank).

\section{Effective Strategy Implementation in Loan Syndications}

In this section we consider the key development phases of the Loan Syndications department: (i) establishment; (ii) diversification; (iii) expansion; (iv) crisis; (v) post-crisis. We consider the key parameters of the business: organisation structure, headcount, functionality, number of deals, loan portfolio size. Note, we provided the numerical examples for illustrative purposes to demonstrate the scale and dynamics of the business.

\section{Establishment}

In our example, the Loan Syndications department is established as part of the Global Financing division of an international bank. This stage involves setting-up the internal processes, strat- egy, and managerial accounting. The clients are limited to the largest corporations. During this phase, the department is focused on two functions: participation as Lender in corporate syndicated loans in the primary market and acquisition of commitments in corporate syndicated loans in the secondary market.

The average number of transactions per annum is five corporate syndicated loans. Total headcount at this stage is three bankers (including one department head). In terms of timing, the first phase can take two years. The accumulated loan portfolio is USD $300 \mathrm{mln}$.

\section{Diversification}

At the second stage, the department is growing and diversifying its products offering, client base and transactional functions. In addition to corporate syndicated loans, syndicated real estate finance transactions are executed. Financial institutions, in addition to corporations, are being serviced. The department starts playing a more advanced role in transactions, taking on the Mandated Lead Arranger status.

The total number of deals executed annually is 10 :

- Five syndicated corporate loans.

- Three syndicated financial institutions loans.

- Two syndicated real estate finance transaction.

The structure of the department includes three units: Corporate Loans, Financial Institutions loans, Real Estate finance. The total headcount is seven bankers, with two bankers in each unit and one department head. There is a corresponding refinement of the internal processes and documents. The diversification stage usually lasts three years. The accumulated loan portfolio is USD 500 million. 


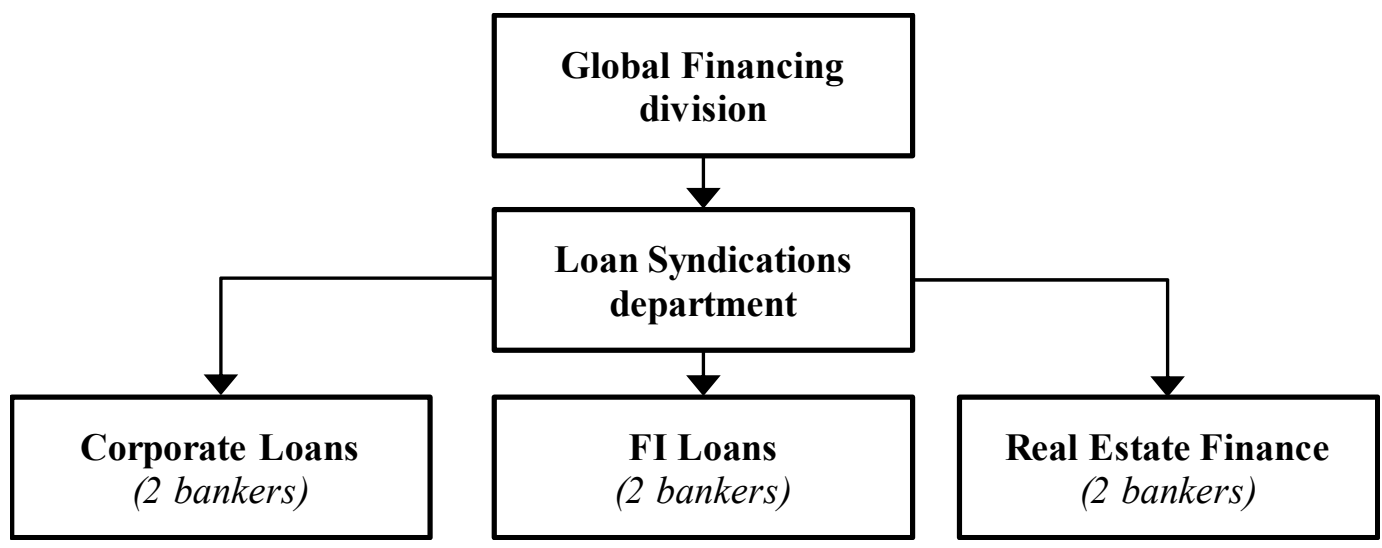

Fig. 2. The organisation structure of the Loan Syndications department in the diversification phase.

Source: The author.

\section{Expansion}

In many ways, this is the key development stage, with several significant events. Firstly, two new products are added to the spectrum: pre-export finance (specialised financing focused on secured loans for leading exporters) and project finance (long-term greenfield transactions for industry, transport, and infrastructure). In terms of functionality, there are three principal themes: (i) acting as Coordinator; (ii) managing the accumulated loan portfolio of the department (which at this stage exceeds USD 1,000 million); (iii) selling loan commitments in the secondary market.

The transactional activity of the department can be summarised in the following way:

- Ten syndicated corporate loans.

- Five syndicated financial institution loans.

- Three syndicated real estate transactions.

- One syndicated pre-export finance deal.

- One syndicated project finance deal.

The organisation of the department includes two additional units: Structured Finance and Portfolio Management. Total staff is ten bankers (three in Corporate Loans, two in Financial Institutions loans, two in Real Estate Finance, one in Structured Finance, one in Portfolio Management, one department head). A successful expansion phase should last five years. At the end of this period, the loan portfolio totals USD 1,500 million.

\section{Crisis}

Like all financial markets, the syndicated loan market is characterised by a crisis. During such periods, activity comes to a halt, and the focus of the business is on restructuring. In the considered case, there is limited activity in syndi- cated corporate loans and structured finance, no new business in syndicated financial institutions loans, partly restructuring in portfolio management, substantial restructuring in real estate finance.

The deal flow in this crisis environment includes:

- Three syndicated corporate loans.

- Two syndicated pre-export finance deals.

- Ten syndicated corporate and real estate loans restructurings.

This market scenario has several significant implications for the Loan Syndication department:

- Since financial institutions are profoundly affected by the crisis, this unit is closed.

- The Real Estate finance unit, with legacy loan portfolio and staff, is wholly transferred out of the Loan Syndications department to the Restructuring department.

- The syndicated corporate loans unit is combined with the structured finance unit into the new Corporate \& Structured Finance unit with a focus on staff optimisation and capital allocation.

- A lawyer and a credit analyst are added to the Portfolio Management unit that is now called the Support unit.

The total headcount of the department is eight bankers (four in the Corporate \& Structured Finance unit, three in the Support unit, one department head). The crisis phase usually lasts $2-3$ years. The size of the loan portfolio decreases to USD 800 million.

\section{Post-crisis}

Further, a new strategy should be formulated for the Loans Syndications department. It includes 


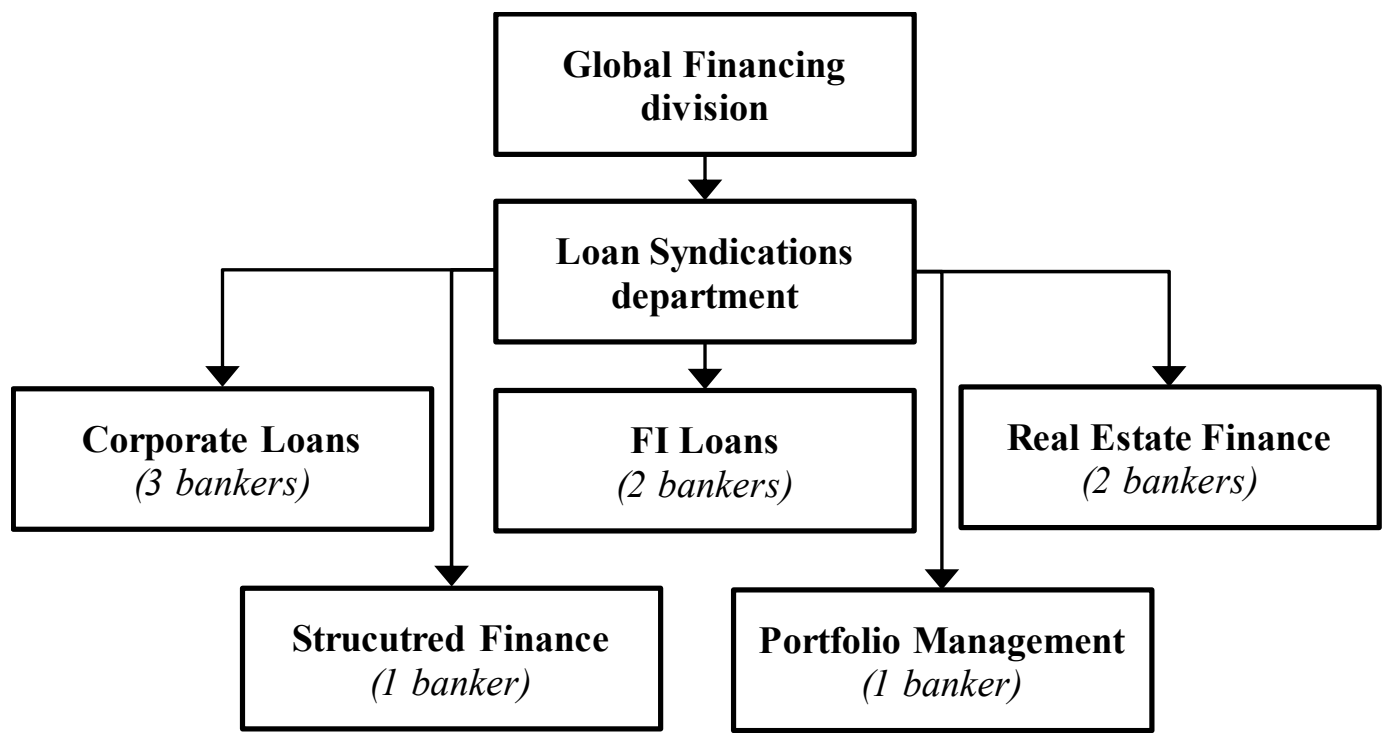

Fig. 3. The organisation structure of the Loan Syndications department in the expansion phase.

Source: The author.

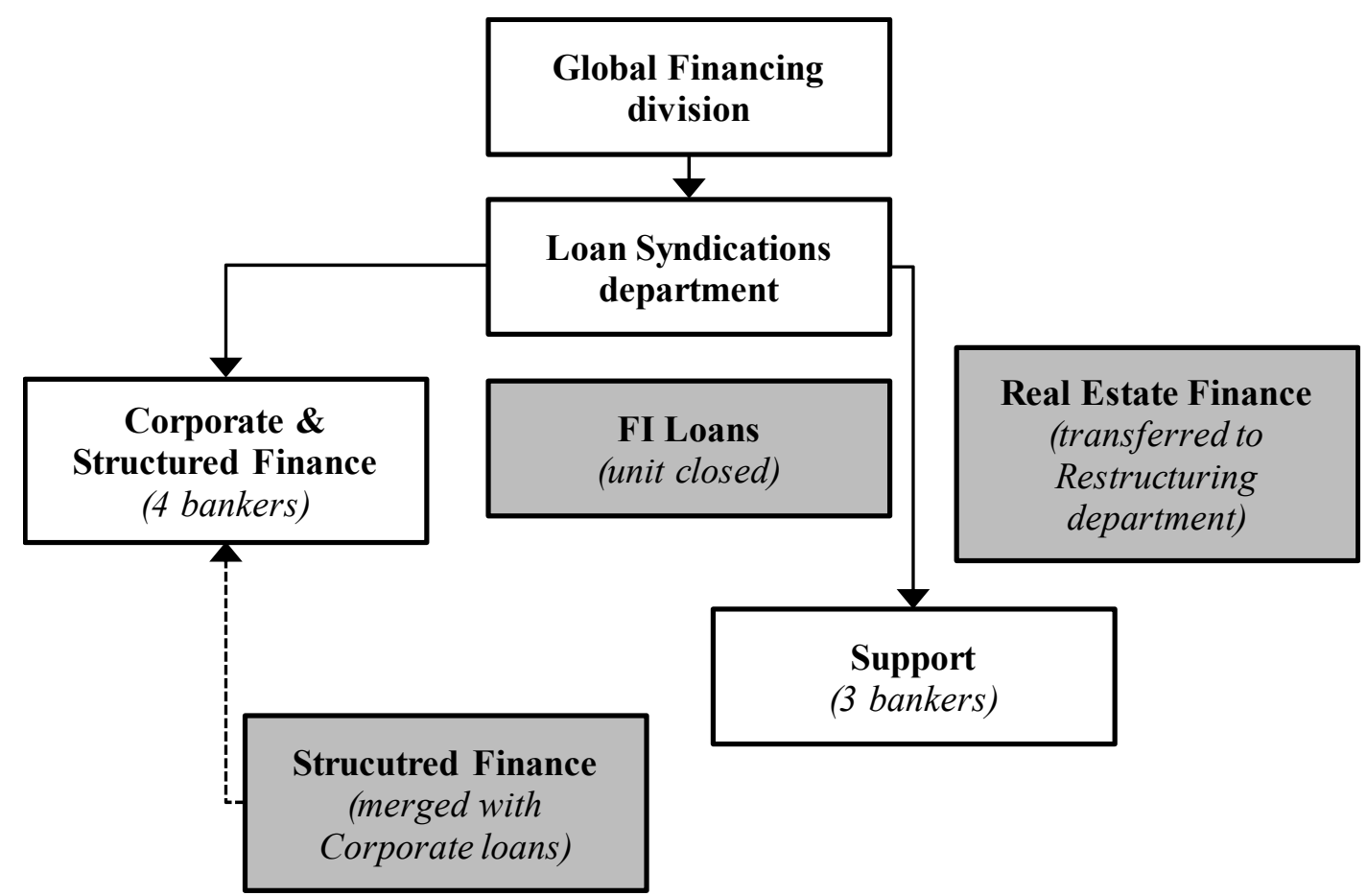

Fig. 4. The organisation structure of the Loan Syndications department in the crisis phase.

Source: The author.

the most important lessons of the crisis and focuses the business on new market realities.

This strategy includes the following components:

- Achieve leadership in the syndicated corporate loans and structured finance markets, measured as top-10 market share.

- Execute annually up to 12 syndicated corporate loans, five syndicated structured finance deals, with the achievement of the KPIs regarding net banking income and asset creation for the bank. The total size of the syndicated loans portfolios should be USD 1,200 million.

- Expand the Support unit, to provide legal and credit analysis input for a smoother execution process (previously these functions were done by the Legal and Credit Analysis departments of the banks), as well as backoffice functions for the management of the portfolio.

- Establish an Advisory unit that will work with the clients of the bank to provide services 


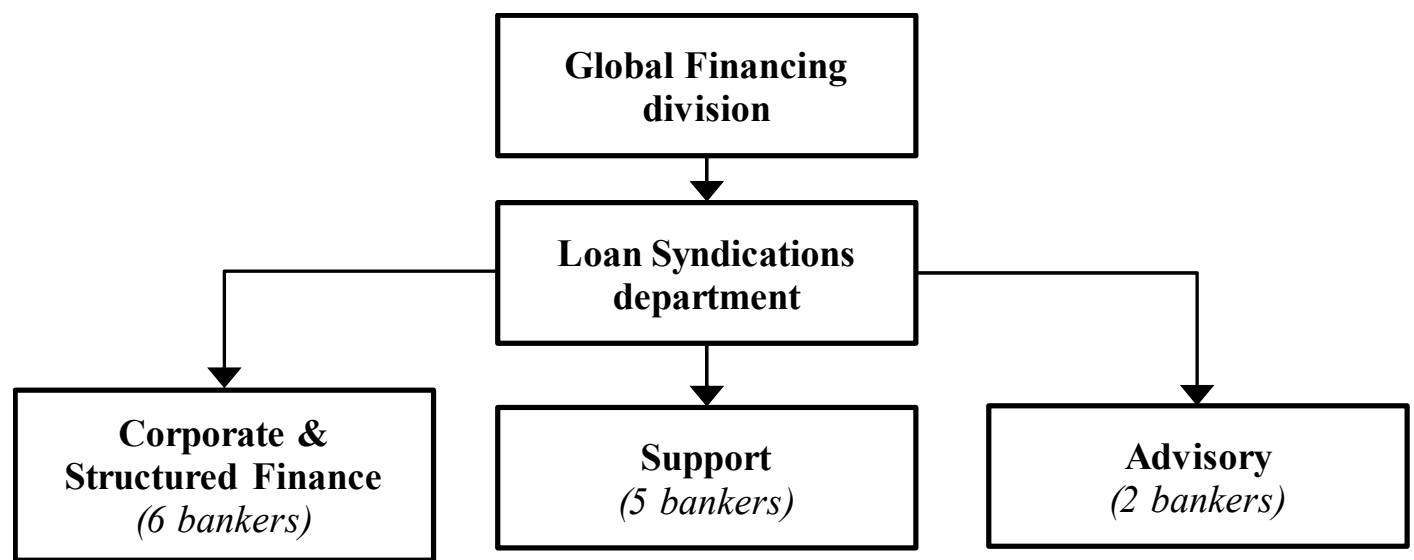

Fig. 5. The organisation structure of the Loan Syndications department in the post-crisis phase.

Source: The author.

on optimal capital structure and mergers \& acquisitions.

- The total headcount of the department 14 bankers (six in the Corporate \& Structured Finance unit, five in the Support unit, two in the Advisory Unit, one department head).

Based on the description of the five development phases, we can present the following illustration of the strategic evolution of the loan syndications business:

We can return to Fig. 1 and demonstrate how strategy and target structure for the Loan Syndications department reflects its importance in the "mission critical/growth" framework:

- High risk: the establishment of the middle-office support function in the form of Legal and Credit Analysis team is clearly intended to create a focused response to the two most significant risks in syndicated and structured finance transactions: (i) legal risks arising from the bank becoming a party to loan documentation; (ii) credit risk from lending to Borrowers.

- The high degree of freedom: in addition to the middle-office, the creation of the back-office and the advisory unit are intended to create a vertically-integrated efficient structure, with a limit on time-consuming interaction with other departments of the bank (legal, operations, risk) that may be involved in loan deals.

Regarding the main difficulties in implementing this strategy, the following issues may be highlighted:

- Internal: (i) limitations on capital available for loan deals; (ii) risk-management constraints; (iii) conflicts with other departments within the bank involved in working with corporate customers.

- External: (i) macroeconomics (liquidity, funding needs); (ii) competitive pressures (banks offering lower pricing); (iii) force majeure events like the global 2008 financial crisis that had a significant effect on the financial market.

\section{Fighting the Commodity Magnet and the Process of Commoditisation}

A significant challenge for global banks is that the syndicated loans market is becoming highly commoditised. This is due to several factors: (i) more international banks entering the loan market leading to intense competition for top borrowers; (ii) borrowers becoming more sophisticated by "understanding the product by doing deals" and expanding the number of relationship banks; (iii) generally, falling financing costs for the top borrowers.

By analysing the industry, the following factors can be proposed as key for differentiation in the market:

- Capital that is allocated for syndicated lending activity (availability of capital is the most important competitive factor for banks).

- Cost of funds for banks that are directly correlated to the financing costs for borrowers.

- Availability of additional high-quality services for clients.

The first two points are strategic issues for all global banks, affecting all business lines. We can, therefore, focus on the third point: services. For the formulation of a strategic response to commoditization, leading loan market banks are adopting the following strategy to differentiate themselves from competitors: 


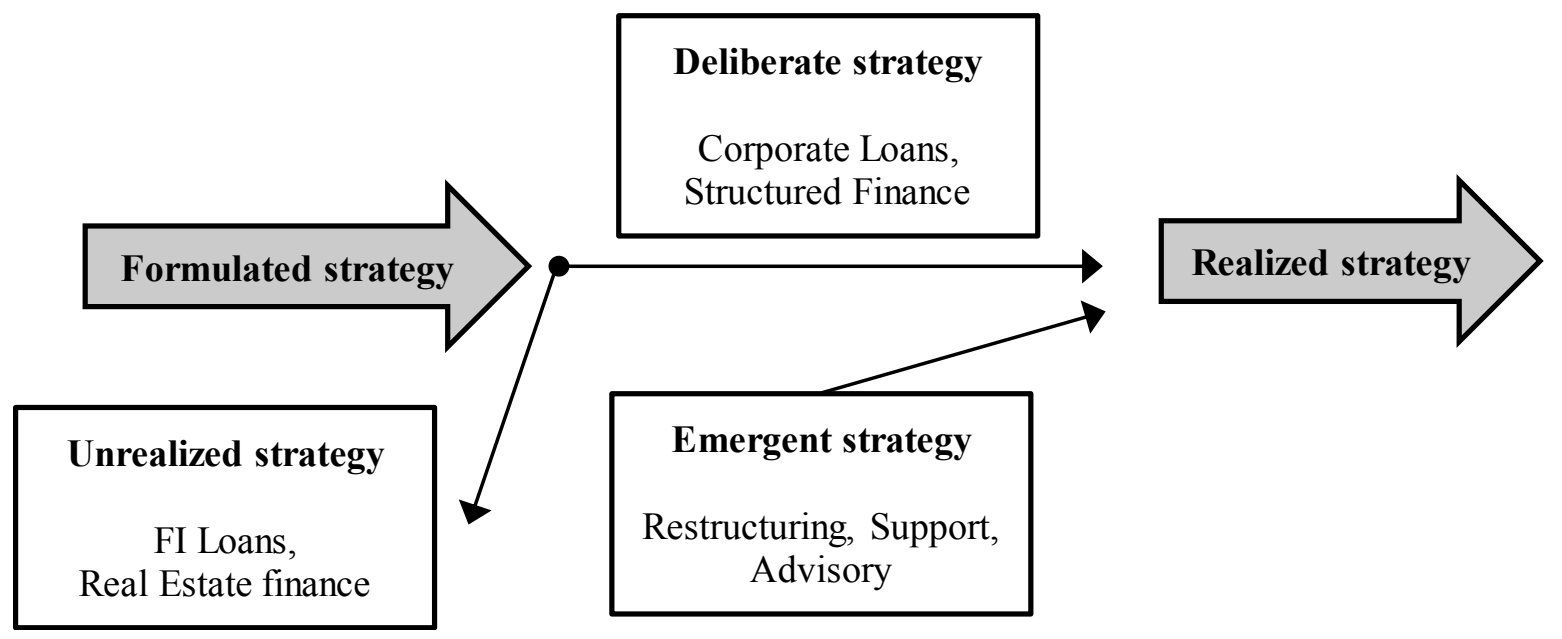

Fig. 6. "Formulated versus Realized" strategy of the Loan Syndications department.

Source: Compiled by the author.

- Adding more value-added services to their corporate offering: advisory, deal coordination, agency services, derivatives, currency operations, loan management, legal support.

- Bundling of services to realise cross-selling opportunities and maximise share-of-wallet.

- Further segmentation and customisation of the client base (by industry/relationship/services consumption) to formulate the best-bundled offering for each client.

For such a value-added strategy, a competencebased view of marketing, as outlined in (Matthyssens, Vandenbempt, \& Weyns, 2009), is particularly important, since "especially when selling professional services, the marketer cannot rely solely on technology upgrades, but needs to grow several competences simultaneously", including consistent bundles of 'processes and systems', 'assets, knowledge and capabilities' and 'culture and organization' that have to be built in order to sustain a value-added marketing strategy.

Several value-innovation initiatives for industrial companies are summarised in (Matthyssens, VandenbemptБ \& Berghman, 2006). If we apply this approach to the loan syndications business, we can outline the following bundling initiative: banks increasingly want to be present in every stage of the financing process. This is done by expanding the loan offering to "both sides" of the loan deal, as well as additional services during the execution process: (i) pre-execution, advisory on best debt raising solution and subsequent structuring of the deal; (ii) execution: handling the investor base, covering the legal issues; (iii) post-execution: management of the transaction by offering payment/currency services, derivatives, portfolio management.

In addition to this, banks are also increasing their role in the execution process: preparing the legal documentations, drafting the marketing materials, handling communication with the relationship banks of the borrower. These initiatives lead to a stronger relationship with the client that ultimately leads to higher fees and a realisation of the cross-sale strategy.

Such an expansion of the offering requires substantial resources in products, human capital and IT, as well as a strong organisational structure that functions without major bottlenecks. However, such investment does pay-off as by executing several successful deals for its client, the bank acquires a sound reputation in the market and further build upon its unique offering.

In the "typology of service" framework in (Matthyssens \& Vandenbempt, 2010), banks try to tailor their offering to cover the funding and services needs of the client as widely and deeply as possible, acting as "value partners" offering customised services to their clients. It is done by providing an integrated process solution (running the deal "from A to Z") and concentrating on lucrative tailor-made services like hedging and legal advice.

Summarising, by bundling high commoditised products and services (provision of loans, agency functions, currency services) with low commoditised ones (advisory, structuring, derivatives), banks can successfully fight the commoditization magnet and increase the profitability of their loans syndications businesses. 


\section{References}

Allen, L., Peristian, S., \& Saunders, A. (2004). The Role of Bank Advisors in Mergers and Acquisitions, Journal of Money, Credit, and Banking, 36(2), 197-224.

Altunbas, Y., Gadanecz, B., \& Kara, A. (2006). Syndicated Loans: Hybrid of Relationship Lending and Publicly Traded Debt. Palgrave Macmillan.

Bloomberg. Global Syndicated Loans 2018. Retrieved from https://data.bloomberglp.com/professional/sites/10/ Bloomberg-Global-Syndicated-Loans-League-Tables-FY-2018.pdf

Caselli, S., \& Gatti, S. (2017). Structured Finance: Techniques, Products and Market. Springer.

Davis, S. (2002). Investment Banking: Addressing the Management Issues. Palgrave Macmillan.

Dennis, S., \& Mullineaux, D. (2000). Syndicated Loans. Journal of Financial Intermediation, 9(4), 404-426.

Francis, J., \& Kim, D. (2013). Modern Portfolio Theory: Foundations, Analysis, and New Developments. Wiley, 554 p.

Iannotta, G. (2010). Investment Banking: A Guide to Underwriting and Advisory Services. Springer.

Matthyssens, P., \& Vandenbempt, K. (2010). Service Addition as Business Market Strategy: Identification of Transition Trajectories. Journal of Service Management, 21(5), 693-714.

Matthyssens, P., Vandenbempt, K., \& Berghman, L. (2006). Value Innovation in Business Markets: Breaking the Industry Recipe. Industrial Marketing Management, 35(6), 751-761.

Matthyssens, P., Vandenbempt, K., \& Weyns, S. (2009). Transitioning and Co-evolving to Upgrade Value Offerings: Competence-based Marketing View. Industrial Marketing Management, 38(5), 504-512.

O’Reilly, C., \& Tushman, M. (2011). Organizational Ambidexterity in Action: How managers Explore and Exploit. California Management Review, 53(4), 5-22.

Schwert, M. (2018). Bank Capital and Lending Relationships. The Journal of Finance, 73(2), 787-830.

Shutter, A. (2017). A Practitioner's Guide to Syndicated Lending. Sweet \& Maxwell.

Tarasov, A. (2017). Underwriting Syndicated Loans in the Russian Market. Review of Business and Economic Studies, 3, 45-51.

Wystup, U. (2017). FX Options and Structured Products. Wiley.

\section{Вопросы менеджмента в банковском синдицированном кредитовании}

\section{Алексей Тарасов}

Кандидат экономических наук,

Executive MBA,

Москва, Россия

alexey.tarasov@outlook.com

http://orcid.org/0000-0002-7902-5619

Аннотация. Исследованы ключевые аспекты организации и управления синдицированного кредитования в банке. Дан всесторонний анализ особенностям международного рынка синдицированного кредитования, который одновременно является крупнейшим источником финансирования для корпораций и одним из ключевых сегментов банковского бизнеса. Предложены проверенные практикой решения, позволяющие банкам успешно реагировать на современные вызовы коммодитизации (добавление к базовым банковским продуктам высокодоходных услуг; объединение услуг для получения максимального дохода от каждого клиента; сегментация клиентской базы с целью соответствия интегрированного предложения потребностям различных клиентов). Используя данные рекомендации, банки могут успешно развивать бизнес синдицированного кредитования, увеличивая прибыль и долю рынка.

Ключевые слова: банковский бизнес; синдицированные кредиты; банковский менеджмент; коммодитизация; международные рынки капитала 